\title{
DNA methylation fluctuation induced by virus infection differs between MD-resistant and -susceptible chickens
}

\author{
Juan Luo ${ }^{1 \neq}$, Ying Yu ${ }^{1+\neq}$, Shuang Chang ${ }^{2,3}$, Fei Tian' ${ }^{1}$, Huanmin Zhang ${ }^{2}$ and Jiuzhou Song ${ }^{*}$ \\ ${ }^{1}$ Department of Animal and Avian Sciences, University of Maryland, College Park, MD, USA \\ ${ }^{2}$ Avian Disease and Oncology Laboratory, The United States Department of Agriculture, Agricultural Research Service, East Lansing, MI, USA \\ ${ }^{3}$ Department of Animal Science, Michigan State University, East Lansing, MI, USA
}

\section{Edited by: \\ Xiangqin Cui, University of Alabama at \\ Birmingham, USA \\ Reviewed by: \\ Hao Wu, Emory University, USA \\ Liang Liu, Columbia University, USA \\ *Correspondence: \\ Jiuzhou Song, Department of Animal and Avian Sciences, University of \\ Maryland, College Park, MD 20742, \\ USA. \\ e-mail: songj88@umd.edu}

${ }^{\dagger}$ Present address:

Ying Yu, Department of Animal Breeding and Genetics, College of Animal Sciences, China Agricultural University, Beijing 100193, China.

${ }^{\ddagger}$ Juan Luo and Ying Yu have contributed equally to this work.
Marek's disease (MD) is a lymphoproliferative disease induced by Marek's disease virus (MDV) infection. To augment vaccination measures in MD control, host genetic resistant to MD becomes obviously more and more important. To elucidate the mechanism of MDresistance, most of researches were focused on the genetic differences between resistant and susceptible chickens. However, epigenetic features between MD resistant and susceptible chickens are poorly characterized. Using bisulfite pyrosequencing method, we found some candidate genes have higher promoter methylation in the MD-susceptible $\left(L 7_{2}\right)$ chickens than in the MD-resistant (L63) chickens. The hypermethylated genes, involved in cellular component organization, responding to stimulus, cell adhesion, and immune system process, may play important role in susceptibility to disease by deregulation of these genes. MDV infection induced the expression changes of all three methyltransferases genes (DNMT1, DNMT3a, and DNMT3b) in both lines of chickens. The DNMT1 was upregulated in $\mathrm{L}_{2}$, whereas the DNMT3b was down-regulated in $\mathrm{L}_{3}$ at 21 dpi. Interestingly, a dynamic change of promoter methylation was observed during MDV life cycle. Some genes, including HDAC9, GH, STAT1, CIITA, FABP3, LATS2, and H2AC, showed differential methylation behaviors between the two lines of chickens. In summary, the findings from this study suggested that DNA methylation heterogeneity and MDV infection induced methylation alterations differences existed between the two lines of chickens. Therefore, it is suggested that epigenetic mechanisms may be involved in modulating the resistance and/or susceptibility to MD in chickens.

Keywords: chicken, Marek's disease, MD-resistance, MD-susceptibility, DNA methylation

\section{INTRODUCTION}

Marek's disease (MD) is a lymphoproliferative disease of chickens caused by Marek's disease virus (MDV) with pathological features including mononuclear cell-infiltration in the peripheral nerves, skin, and muscle (Davison and Nair, 2004). MDV is classified into the Mardivirus genus due to its genome content (Davison, 2002) and biological effect on lymphocytes like EBV (Epstein, 2001). MDV life cycle in its host can be divided into four phases, including an early cytolytic phase from 2 to 7 days post infection (dpi), a latency phase around 7-10 dpi, a late cytolytic phase starting from $18 \mathrm{dpi}$ and a proliferation phase after $28 \mathrm{dpi}$ (Calnek, 1986, 2001). Although MD is controlled by vaccination, the virulence of MDV has being evolved over time and resulted in more severe brain edema and acute deaths even after vaccination (Witter, 1997; Osterrieder et al., 2006). MD remains a problem in the poultry industry worldwide (Churchill et al., 1969). Since the inheritance and resistance to MD was first observed (Asmundson and Biely, 1932), MD-resistant and -susceptible chickens have been bred by those including Stone (lines 6 and 7; Bacon et al., 2000), Hutt, and Cole (lines N and P; Davison and Nair, 2004). Nowadays, the selection of genetically disease resistant chickens is especially important in MD control. A better understanding in the mechanisms of MD-resistance and -susceptibility should be of great value in developing better strategies to further prevent and control MD.

In recent years, most of the studies are focused on genetic variations between MD-resistant and susceptible chickens (Gilmour et al., 1976; Fredericksen et al., 1977; Kaiser et al., 2003; Sarson et al., 2008a). However, little is done on epigenetic differences between the two kinds of chickens. Epigenetics is the study of alterations in phenotypes that are not brought about by changes in DNA sequences, but by factors including DNA methylation, histone modifications, and so on (Allis et al., 2006). DNA methylation is known as a post-replication modification found on the 5 -C position of cytosine mainly in $\mathrm{CpG}$ dinucleotides, generated and maintained by three methyltransferases - DNMT1, DNMT3a, and DNMT3b (Allis et al., 2006). In mammals, DNA methylation was found playing important role in development, imprinting, carcinogenesis, and other diseases (Feinberg and Tycko, 2004; Feng et al., 2010). Notably, we found two DNA mutations in DNMT3b (Yu et al., 2008a) and a higher promoter methylation level of $A L V E$ and TVB in the spleen of MD-susceptible chickens $\left(\mathrm{L7}_{2}\right)$ compared to that of MD-resistant chickens (L6 3 ; Yu et al., 2008b), and the methylation level in CD4 promoter region was 
down-regulated in the former but not in the later at $21 \mathrm{dpi}$ (Luo et al., 2011).

To advance the understanding of functional patterns of DNA methylation in disease resistance or susceptibility, we extended the scope of examination to 18 interested genes, which include STAT1, CIITA, NK-lysin, CD44, IL12, and GH1 that the expression levels of these gene are alterable upon MDV challenge (Liu et al., 2001; Abdul-Careem et al., 2006; Parcells and Burgess, 2008; Sarson et al., 2008a,b; Heidari et al., 2010; Thanthrige-Don et al., 2010). Some of the 18 genes were also chosen based on our previous temporal microarray data, which include FABP3, HDAC9, IL28RA, MON2, and THBS2 (Luo et al., 2011; Yu et al., 2011).

\section{MATERIALS AND METHODS}

\section{ANIMALS, CHALLENGE TRIAL, AND SAMPLE COLLECTION}

Specific pathogen free chickens from two highly inbred White Leghorn lines, the $\mathrm{L}_{3}$ and $\mathrm{L}_{2}$, were used. Chickens from each of the lines were divided into two groups. One group was challenged with a very virulent plus MDV (vv + MDV), 648A passage 40, intra-abdominally at day 5 post hatch at a 500 plaque-forming unit (PFU) dosage, the other was not challenged and was assigned as the control group. Fresh spleen samples were respectively collected at 5, 10, and $21 \mathrm{dpi}$ from both groups, and placed in RNAlater (Qiagen, Valencia, CA, USA) immediately, and then stored at $-80^{\circ} \mathrm{C}$.

All of the experimental chickens were challenged and maintained in a BSL-2 facility at the Avian Disease and Oncology Laboratory (ADOL), East Lansing, Michigan. The chickens were handled closely following animal usage procedures established by the ADOL ACUC committee.

\section{DNA EXTRACTION, BISULFITE TREATMENT, AND PYROSEOUENCING}

DNA was extracted from $20 \sim 30 \mathrm{mg}$ spleen by NucleoSpin ${ }^{\circledR}$ Tissue Kits (Macherey-Nagel, Bethlehem, PA, USA). Bisulfite treatment of $1 \mu \mathrm{g}$ DNA per chicken was performed using EZ DNA Methylation-Gold $\mathrm{Kit}^{\mathrm{TM}}$ (ZYMO Research, Irvine, CA, USA). Primers for PCR and pyrosequencing were designed with PSQ Assay Design software (Biotage, Charlotte, NC, USA; Table A1 in Appendix). For cost saving purposes, a universal primer $\left(5^{\prime}\right.$ GGGACACCGCTGATCGTTTA-3') was used in the PCR assays (Yu et al., 2008a). PCR was carried out using Hotstar Taq DNA polymerase (Qiagen, Valencia, CA, USA) in $20 \mu \mathrm{l}$ reactions in iCycler (Bio-Rad, Hercules, CA, USA) Detection System as follows: samples were denatured at $95^{\circ} \mathrm{C}$ for $15 \mathrm{~min}$, followed by 50 cycles at $95^{\circ} \mathrm{C}$ for $30 \mathrm{~s}, 55-60^{\circ} \mathrm{C}$ for $30 \mathrm{~s}, 72^{\circ} \mathrm{C}$ for $30 \mathrm{~s}$, and then extended at $72^{\circ} \mathrm{C}$ for $10 \mathrm{~min}$. DNA methylation level analysis was performed on the Pyro Q-CpG system (PyroMark ID, Biotage, Charlotte, NC, USA) as previously described (Colella et al., 2003; Yu et al., 2008a).

\section{RNA EXTRACTION AND OUANTITATIVE REAL-TIME RT-PCR}

RNA from $30 \sim 50 \mathrm{mg}$ spleen was extracted using the RNeasy Mini Kit (Qiagen, USA). Reverse transcription was carried out in $20 \mu \mathrm{l}$ with $1 \mu \mathrm{g}$ of total RNA by using SuperScriptTM III Reverse Transcriptase (Invitrogen, Carlsbad, CA, USA) and oligo (dT)12-18 primers (Invitrogen, Carlsbad, CA, USA). Primers (Table A2 in Appendix) for quantitative real-time RT-PCR were designed using
Primer3 online primer designer system ${ }^{1}$. Quantitative real-time RT-PCR was performed on the iCycler iQ PCR system (Bio-Rad, USA) in a final volume of $20 \mu \mathrm{l}$ using QuantiTect SYBR Green PCR Kit (Qiagen) with following procedures: denatured at $95^{\circ} \mathrm{C}$ for $15 \mathrm{~min}$, followed by 40 cycles at $95^{\circ} \mathrm{C}$ for $30 \mathrm{~s}, 55-60^{\circ} \mathrm{C}$ for $30 \mathrm{~s}$, $72^{\circ} \mathrm{C}$ for $30 \mathrm{~s}$, then extended at $72^{\circ} \mathrm{C}$ for $10 \mathrm{~min}$. Each reaction was replicated. The housekeeping gene GAPDH (glyceraldehyde3-phosphate dehydrogenase) was used to normalize the loading amount of cDNA.

\section{FUNCTIONAL ANALYSIS AND STATISTICS}

The GO Biological Process analysis of the genes was analyzed by PANTHER $^{2}$. Student's $t$-test was used to analyze the differences of the promoter methylation level and the gene expression before and after MDV infection.

\section{RESULTS}

DIFFERENTIAL METHYLATION PATTERNS BETWEEN THE L6 $\mathbf{C}_{\mathbf{3}}$ AND $\mathbf{L 7}_{\mathbf{2}}$

To determine the different methylation levels of genes between the $\mathrm{MD}$-resistant $\mathrm{L}_{3}$ and the MD-susceptible $\mathrm{L}_{2}$ chickens, we analyzed the DNA methylation status of promoters for 18 genes by bisulfite pyrosequencing method. The results showed that most of the 18 genes, including LATS2, MON2, IL28RA, STAT1, CD44, H2Ac, TNFSF10, IL12, FABP3, and CIITA, were hypomethylated (methylation level <40\%); few of them, ITGB5, THBS2, and HDAC9, had intermediate methylation level (between $40 \%$ and $60 \%$ ), and the rest (IGF2, GH1, NK-lysin, and TGF 33 ) had hypermethylation methylation level $(>60 \%)$ in the control groups of both lines (Table A3 in Appendix). However, some of the CpGs of CD82 had a very low methylation level $(<10 \%)$ and others had an intermediate methylation level (Table A3 in Appendix).

Differential promoter methylation levels were observed for ITGB5, THBS2, HDAC9, IL12, CD44, H2AC, and TNFSF10 between the $\mathrm{L}_{3}$ and $\mathrm{L7}_{2}$, As showed in Figure 1, the methylation levels in all the tested CpG sites of the ITGB5, THBS2, HDAC9, IL12, H2AC were significantly higher in $\mathrm{L}_{2}$ than in $\mathrm{L}_{3}(P<0.05$; Figures 1A-E). However, some of the $\mathrm{CpG}$ sites in $C D 44$ (CpG 2 and 4) and TNFSF10 (CpG 5) had higher level of methylation $(P<0.05)$, while some others (CD44 CpG 3; TNFSF10 CpG 1 and 3$)$ had lower methylation levels in $\mathrm{L}_{3}$ than $\mathrm{L}_{2}(P<0.05$; Figures 1F,G).

To test if the differential promoter methylation levels of these genes are related with gene expression, we randomly chose two genes, ITGB5 and $H 2 A c$, and did quantitative RT-PCR. We found that the expression levels of the two genes, whose promoter methylation is higher in $\mathrm{L}_{2}$ chicken, is lower in these chickens (Figure 2).

Functional analysis of the genes (Figure 3) showed that, in comparison to the whole gene set we examined in this experiment, genes with lower methylation levels in $\mathrm{L}_{3}$ are mainly enriched in cellular component organization, response to stimulus, cell adhesion, and immune system process. In contrast, an under-enrichment of these genes was shown in cell communication, transport, system process, reproduction, and

\footnotetext{
${ }^{1}$ http://frodo.wi.mit.edu/

${ }^{2}$ http://www.pantherdb.org/
} 


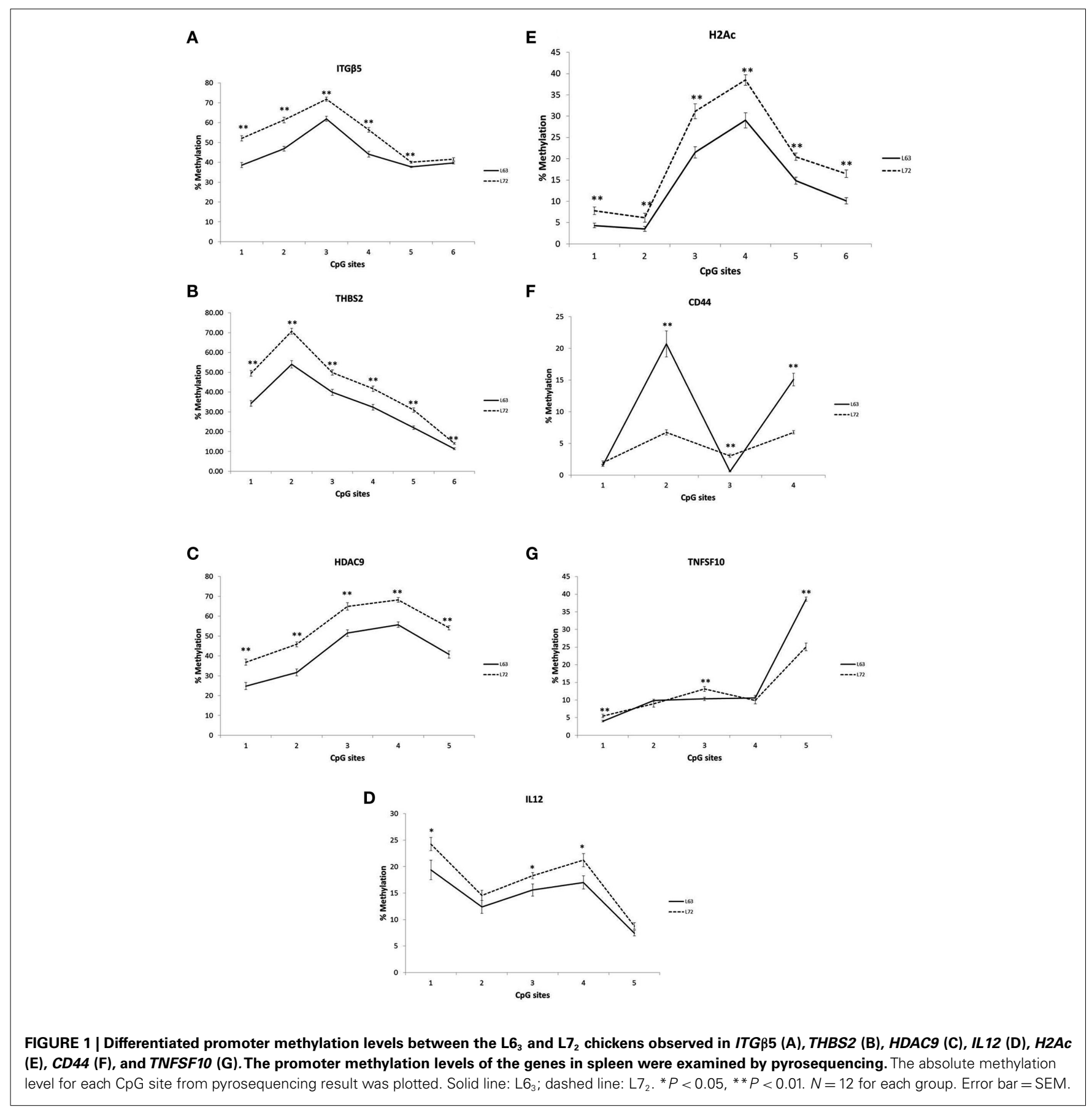

developmental process. For genes with a varied methylation levels between $\mathrm{L6}_{3}$ and $\mathrm{L} 7_{2}$, they are over-represented in functions of cell adhesion and immune system process. However, for the genes with similar methylation between the $\mathrm{L}_{3}$ and $\mathrm{L}_{2}$, no under or over-represented biological functions was identified.

DIFFERENTIAL DNMT1, DNMT3a, AND DNMT3b EXPRESSION INDUCED BY MDV CHALLENGE

To explore how MDV challenge induces DNA methylation alteration, we first checked if the expressions of the methylation agents, three methyltransferases (DNMT1, DNMT3a, and DNMT3b), were influenced over three time points $(5,10$, and $21 \mathrm{dpi})$, which represent the early cytolytic, latent, and later cytolytic phase of the virus life cycle in the host cells, respectively. Interestingly, similar trends of expression changes were observed at 5 and $10 \mathrm{dpi}$ for all three DNMTs in the MDV challenged chickens of both lines (Figure 4), while at $21 \mathrm{dpi}$, the changes were much more complicated. At $21 \mathrm{dpi}$, the DNMT1 was significantly up-regulated in the infected $\mathrm{L}_{2}$ chickens compared to the $\mathrm{L}_{2}$ control group $(P<0.05)$. The DNMT1 was remained 
unchanged, however, between the infected and uninfected $\mathrm{L}_{3}$ groups $(P>0.05$; Figure $\mathbf{4 A})$. For DNMT3a, no expression

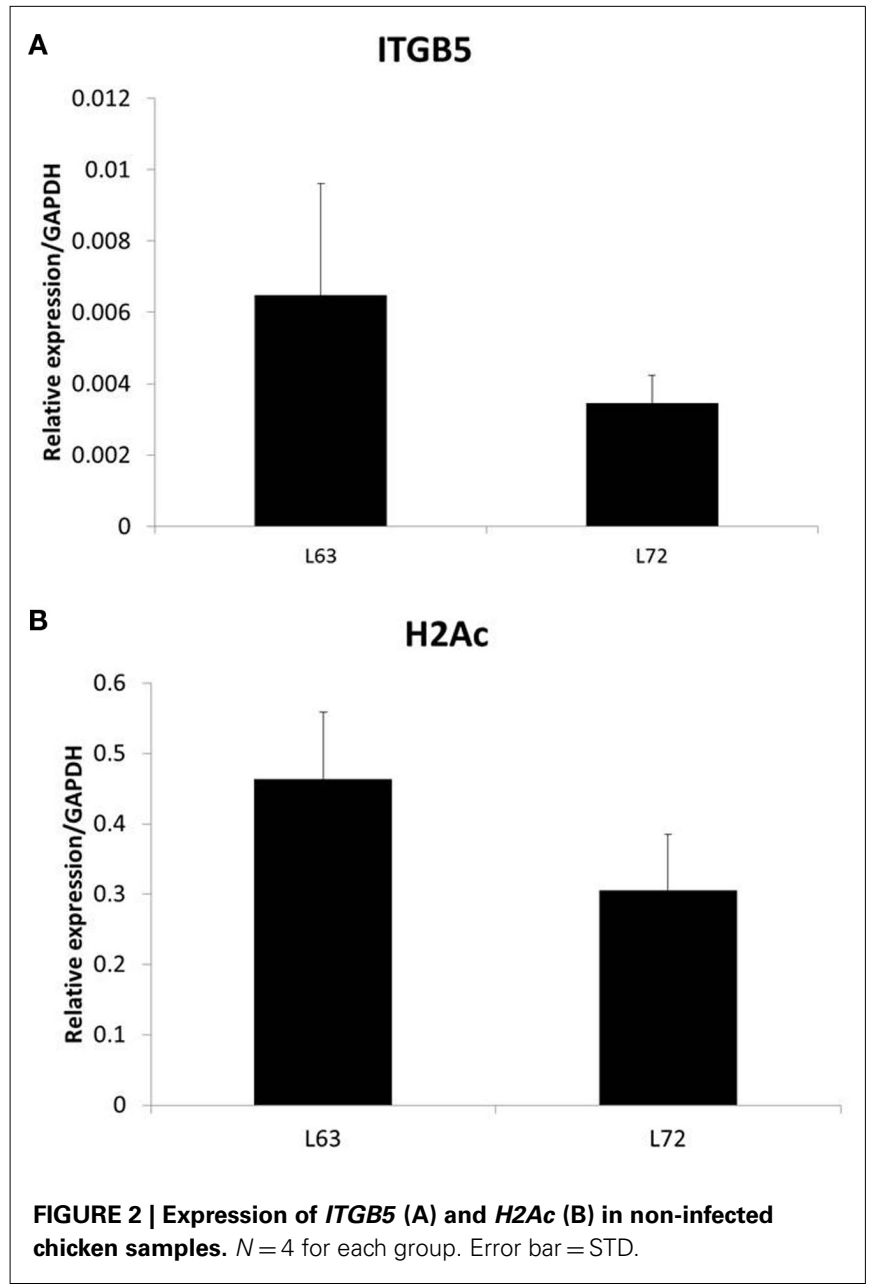

difference was observed at 21 dpi between the infected and noninfected groups of both lines $(P>0.05$; Figure 4B). However, the $D N M T 3 b$ was significantly down-regulated in the infected group of $\mathrm{L6}_{3}$ at $21 \mathrm{dpi}(P<0.05)$, but no differential expression was observed in $\mathrm{L}_{2}$ (Figure 4C). Overall, the expression levels of all the three DNMTs were significantly inducible by MDV infection, but with varied alteration trends and extents were found over different time points and between the infected and non-infected groups as well as between the chicken lines.

\section{ABERRANT METHYLATION LEVEL INDUCED BY MDV INFECTION}

To further study DNA methylation dynamic response to MDV infection, we tested the promoter methylation of the 18 genes on 5, 10, and 21 dpi. Pairwise comparison was performed between the infected and non-infected age-matched sample groups of each chicken line for each of the $\mathrm{CpG}$ sites. Significant methylation level changes $(P<0.05)$ were detected at one or more CpG sites in all of the genes except THBS2 gene after MDV challenge. The methylation level changes of the examined genes were under 30\%. The MDV-induced DNA methylation changes for CIITA, NK-lysin, FABP3, and ITGB5 were $10 \%$ above their unchallenged counterpart for each of the $\mathrm{CpG}$ sites. More than $10 \%$ methylation change was found in HDAC9 at $5 \mathrm{dpi}$ and $7-$ $10 \%$ changes at $21 \mathrm{dpi}$ in $\mathrm{L7}_{2}$. Most of the genes (12/17) had significant methylation change $(P<0.05)$ at more than one time point (Table A4 in Appendix; Figure 5), except for IL12, TNFSF10, and ITGB5, which were only changed at $5 \mathrm{dpi}$, and CD44, LATS2, CIITA, which were only changed at $21 \mathrm{dpi}$. In contrast between the two lines of chickens, more genes in $\mathrm{L}_{3}$ had significant methylation changes at $5 \mathrm{dpi}$, while more genes were observed with significant methylation changes in $\mathrm{L}_{2}$ at 10 and $21 \mathrm{dpi}$ (Figure 6).

\section{DIFFERENTIALLY METHYLATION CHANGES DUE TO MDV CHALLENGE}

To compare the contents of the methylation change between $\mathrm{L}_{3}$ and $\mathrm{L7}_{2}$, the mean methylation change of all the $\mathrm{CpG}$ sites was

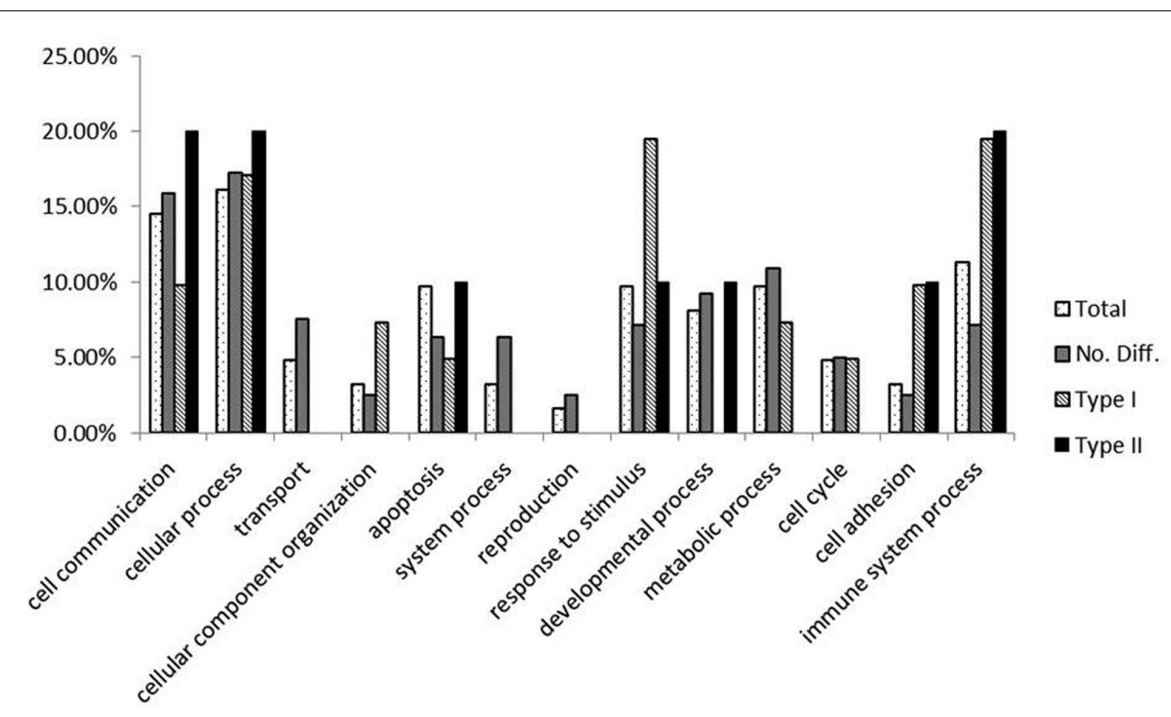

FIGURE 3 | Functional analysis of the genes by PANTHER. 


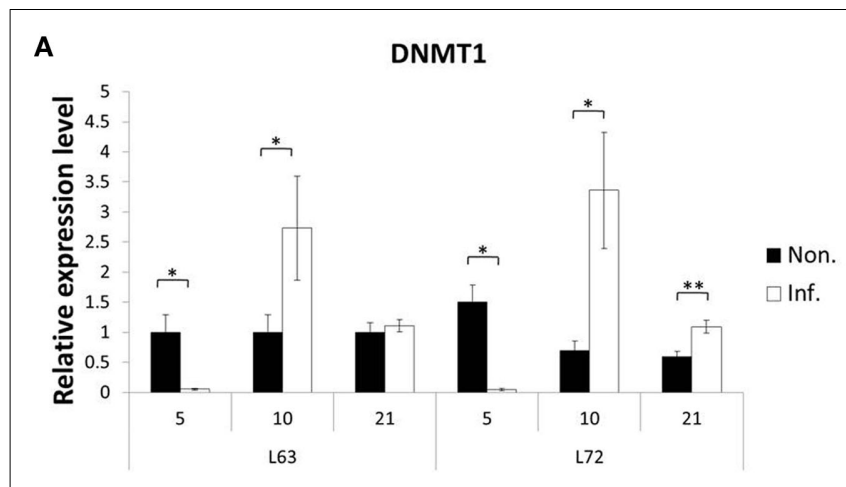

B

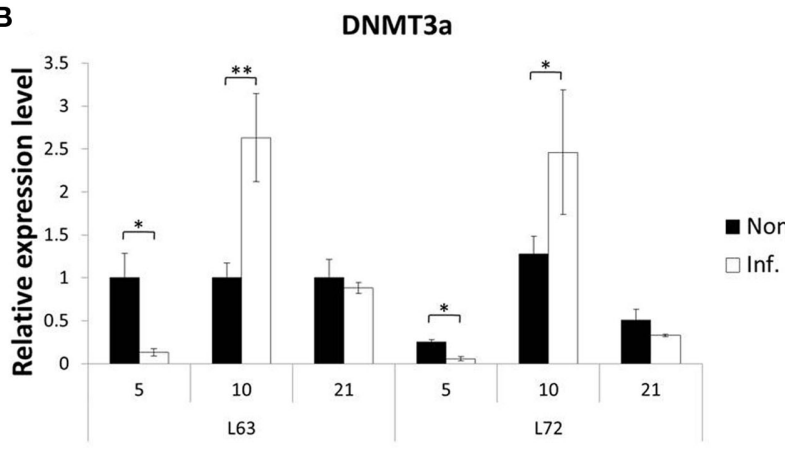

C

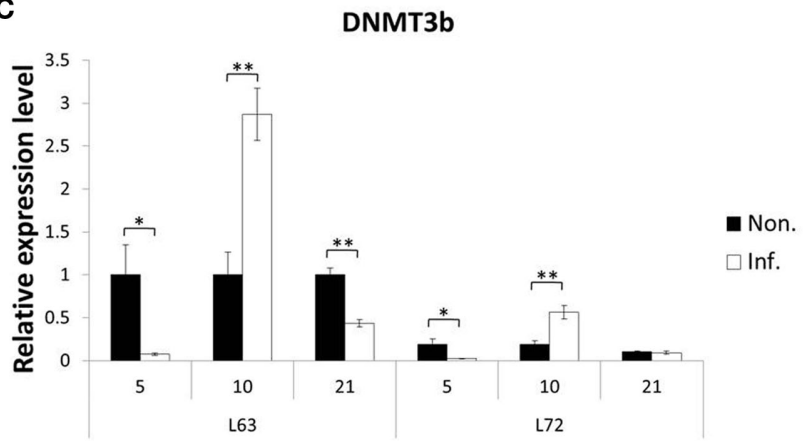

FIGURE 4 | Expression of DNA methyltrasferase genes after MDV infection. The expression of three DNA methyltrasferase genes, DNMT1 (A), DNMT3a (B), and DNMT3b (C), were tested by quantitative real-time RT-PCR at 5, 10, and 21 dpi in chicken spleen both resistant and susceptible to MD. The relative expression level was normalized to GAPDH gene. Black: non-infected; white: infected. ${ }^{*} P<0.05,{ }^{*} P<0.01 . N=4$ for each group. Error bar $=$ SEM.

calculated for each gene. Seven out of the 18 genes (HDAC9, GH, STAT1, CIITA, FABP3, LATS2, and H2Ac) showed significant differentially averaged methylation changes $(P<0.05)$ between the two lines of chickens (Table 1; Figure A1 in Appendix). Functional analysis of the genes with temporal methylation changes revealed that the genes, related to apoptosis, immune system process, and response to stimulus, were over-represented at $5 \mathrm{dpi}$ (Figure 6). However, genes, involved in enrichment of cell communication, were shown at $10 \mathrm{dpi}$; Genes, involved in functionality of cell cycle, cellular component organization, and transport, were over-represented at 10 and 21 dpi.
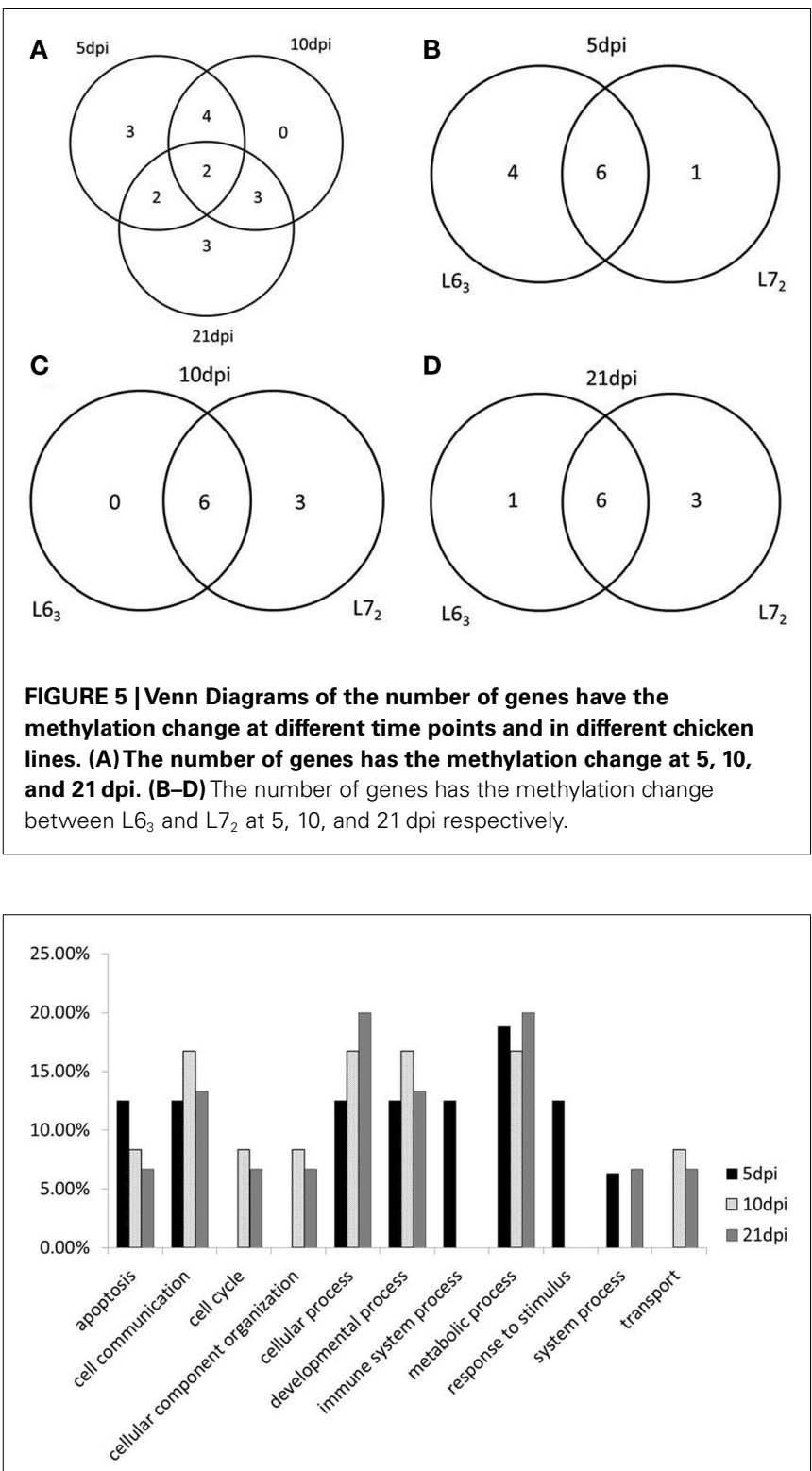

FIGURE 6 | Functional analysis of the genes have different methylation change between $\mathrm{LG}_{3}$ and $\mathrm{L} \mathrm{Z}_{2}$ at 5,10 , and 21 dpi by PANTHER.

\section{DISCUSSION}

The development of disease resistance has long been a very important strategy for control of diseases in farm animals (Bishop et al., 2010; Luo et al., 2012). A better understanding on the mechanisms of disease resistance will facilitate breeding of more disease resistant animals, help to better control diseases in farm animal and also provide better models to learn disease control strategies for humans. Since the establishment of the non-MHC associated MD-resistant and -susceptible chicken lines (Line 6 and Line 7), lots of experiments have been done to elucidate the genetic mechanism of MD-resistance between the two lines of chickens (Gilmour et al., 1976; Fredericksen et al., 1977; Kaiser et al., 2003; Sarson et al., 2008a). However, not until recently, our lab started 
Table 1 | Differential DNA methylation change between $\mathrm{L}_{3}$ and $L 7_{2}$ after MDV challenge.

\begin{tabular}{|c|c|c|c|c|}
\hline \multirow[t]{2}{*}{ Time points (dpi) } & \multirow[t]{2}{*}{ Gene name } & \multicolumn{2}{|c|}{$\begin{array}{l}\text { DNA methylation } \\
\text { level change }\end{array}$} & \multirow[t]{2}{*}{$P$ value } \\
\hline & & $\mathrm{LG}_{3}$ & $\mathrm{LZ}_{2}$ & \\
\hline \multirow[t]{4}{*}{5} & $G H$ & -4.71 & $2.95^{*}$ & 0.0146 \\
\hline & CIITA & 1.95 & $-7.51^{*}$ & 0.0298 \\
\hline & STAT1 & $-0.95^{* *}$ & 0.42 & 0.0244 \\
\hline & $\mathrm{H} 2 \mathrm{Ac}$ & $1.11 * *$ & $2.62 * *$ & 0.0306 \\
\hline \multirow[t]{3}{*}{10} & FABP3 & $4.37^{* *}$ & $-9.21 * *$ & 0.0002 \\
\hline & LATS2 & -0.01 & $0.48^{* *}$ & 0.0409 \\
\hline & $\mathrm{H} 2 \mathrm{AC}$ & $2.53^{* *}$ & -0.56 & 0.0044 \\
\hline \multirow[t]{4}{*}{21} & HDAC9 & $3.16^{* *}$ & $7.92^{* *}$ & 0.0273 \\
\hline & $G H$ & 0.83 & $6.07 * *$ & 0.0096 \\
\hline & FABP3 & -1.76 & $4.70^{* *}$ & 0.0117 \\
\hline & $\mathrm{H} 2 \mathrm{Ac}$ & $0.78^{* *}$ & -1.36 & 0.0211 \\
\hline
\end{tabular}

${ }^{*} P<0.05,{ }^{*} P<0.01$.

to explore their epigenetic differences between the chicken lines, which provides evidence that DNA methylation may be involved in MD-resistance or -susceptibility (Yu et al., 2008a,b; Luo et al., 2011). As we know, although the functions of DNA methylation in development, imprinting etc. were reported in mammals, it's still unclear about its function in disease resistance. Previous study in human (Jelinek et al., 2011) and plant (Akimoto et al., 2007) showed that individuals with a higher DNA methylation level in some particular genes are susceptible to diseases or bacterial infection, which is consistent with our finding that a higher methylation level of several genes (ITGB5, THBS2, HDAC9, IL12, and $H 2 A c$ ) were shown in MD-susceptible ( $\left.\mathrm{L}_{2}\right)$ chickens. However, variable methylation level of CD44 and TNFSF10 between $\mathrm{L}_{3}$ and $\mathrm{L}_{2}$ indicated that the hypermethylation in susceptible chickens is not genome-widely. Functioning classification showed that the hypermethylated genes in susceptible chicken are showing functions of cellular component organization, response to stimulus, cell adhesion, and immune system process. Interestingly, hypermethylation of genes functioning in regulating cell adhesion was very important for the development of various cancers in human (Katto and Mahlknecht, 2011). Furthermore, expression analysis of the hypermethylated genes in the susceptible chickens showed a lower expression of these genes. The results indicated that there are specific pathways that may involve in MDsusceptibility or -resistance through hyper- or hypo-methylation of the genes included. In the future, a genome-wide DNA methylation research will be designed, which will help us explore the mechanisms further.

In previous study, the DNA methyltransferase (DNMTs) were usually found up-regulated by virus infection in human cells, like SV40 (Chuang et al., 1997) and EBV (Tsai et al., 2002). However, dynamic change of DNMTs expression was observed in vivo during MD life cycle in chicken. The DNMTs were first downregulated at $5 \mathrm{dpi}$ and then up-regulated at $10 \mathrm{dpi}$ in both $\mathrm{L}_{3}$ and $\mathrm{L}_{2}$ chickens. Furthermore, different regulations of DNMTs were observed between the MD-resistant and -susceptible chickens at $21 \mathrm{dpi}$, indicating that late cytolytic phase is a critical time for DNMTs function in DNA methylation process or tumorigenesis. However, the DNMTs expression change was not necessary for the change of the methylation level change in the genes we studied. The correlation between DNMTs expression and methylation is upon chickens and time point. There are several reasons for that: First, other epigenetic mechanisms involve in the methylation change during MDV infection; second, the changed dosages of DNMTs are not efficient for the change of methylation on these genes; third, other functions of DNMTs involve. Except for establishing and maintaining the DNA methylation in cells, DNMTs also have other functions. The finding that DNMT1 was only up-regulated in MD-susceptible chicken is consistent with the observation that DNMT1 is necessary for establishing and maintaining the transformation state of cells (Bakin and Curran, 1999; Robert et al., 2003). Similarly, DNMT3B deficient mouse embryo fibroblasts were found resistant to virus induced transformation (Soejima et al., 2003), which is consistent with our finding that the down-regulation of DNMT3b was only shown in MD-resistant chicken.

Abnormal DNA methylation is a common feature of human cancer. The fact is that DNA methylation started to be changed from very early stage of transformation process and a stepwise or dynamic change was happened during carcinogenesis (Ehrlich, 2009; Novak et al., 2009). Furthermore, DNA methylation modifications at the promoter regions of genes play a critical role in the intricate host-virus interaction network (Young et al., 2000; Zheng et al., 2008). From our results, the dynamic DNA methylation change during MD progression not only indicated an interaction between MDV and host gene, but also revealed the genes with aberrant methylation level may also involve in virus induced transformation process. During MDV life cycle in chicken spleen, $5 \mathrm{dpi}$ is the early cytolytic phase when B cells and some $\mathrm{T}$ cells were targeted by MDV (Osterrieder et al., 2006). Virus infection in this stage provokes some apoptosis, lymphoid lesion, and inflammation responses in the immune organ (Morimura et al., 1996; Baigent and Davison, 1999). Different methylation change in genes enriched in apoptosis, immune system process, and response to stimulus suggested that the expression of these genes maybe differentially regulated between the MD-resistant and -susceptible chickens, which show different response to MDV infection. Although 10 and 21 dpi represent the latency and later cytolytic or transformation stage of MDV infection, it's very difficult to differentiate them very clearly in vivo since the latently infected cells can be mixed with the transformed cells (Davison and Nair, 2004). So we found some function enrichments like cell communication and transport are shared at 10 and $21 \mathrm{dpi}$. Genes over-represented in cell cycle and cell communications have different DNA methylation changes in $\mathrm{L}_{3}$ and $\mathrm{L}_{2}$ chicken. Since genes involve in cell cycle and cell communication play important role in carcinogenesis (Yamasaki et al., 1995; Hanahan and Weinberg, 2000, 2011), these results suggested that DNA methylation may participate in MD-resistance by disrupting pathways intriguing tumor formation. 
In conclusion, we found DNA methylation heterogeneity between the MD-resistant $\mathrm{L}_{3}$ and -susceptible $\mathrm{L}_{2}$ chickens. The hypermethylation of genes involved in cellular component organization, response to stimulus, cell adhesion, and immune system process may play important role in MD-susceptibility. Different from other viruses, MDV induces a dynamic expression change in DNMTs. Differential methylation changes are observed between resistant and susceptible chickens after MDV infection. All in all, the differential DNA methylation levels and DNA methylation level change induced by MDV challenge between the lines of chickens suggested that DNA methylation may play a role in host resistance and/or susceptibility to MD.

\section{REFERENCES}

Abdul-Careem, M. F., Hunter, B. D., Sarson, A. J., Mayameei, A., Zhou, H., and Sharif, S. (2006). Marek's disease virus-induced transient paralysis is associated with cytokine gene expression in the nervous system. Viral Immunol. 19, 167-176.

Akimoto, K., Katakami, H., Kim, H. J., Ogawa, E., Sano, C. M., Wada, Y., and Sano, H. (2007). Epigenetic inheritance in rice plants. Ann. Bot. 100, 205-217.

Allis, C. D., Jenuwein, T., Reinberg, D., and Caparros, M.-L. (2006). Epigenetics. Cold Spring Harbor: Laboratory Press.

Asmundson, V. S., and Biely, J. (1932). Inheritance and resistance to fowl paralysis (neuro-lymphomatosis gallinarum). Can. J. Res. 6, 171-176.

Bacon, L. D., Hunt, H. D., and Cheng, H. H. (2000). A review of the development of chicken lines to resolve genes determining resistance to diseases. Poult. Sci. 79, 1082-1093.

Baigent, S. J., and Davison, T. F. (1999). Development and composition of lymphoid lesions in the spleens of Marek's disease virus-infected chickens: association with virus spread and the pathogenesis of Marek's disease. Avian Pathol. 28, 4.

Bakin, A. V., and Curran, T. (1999). Role of DNA 5-methylcytosine transferase in cell transformation by fos. Science 283, 387-390.

Bishop, S. C., Axford, R. F. E., Nicholas, F. W., and Owen, J. B. (eds). (2010). Breeding for Disease Resistance in Farm Animals, 3rd Edn. Oxfordshire: CABI.

Calnek, B. W. (1986). Marek's disease a model for herpesvirus oncology. Crit. Rev. Microbiol. 12, 293-320.

Calnek, B. W. (2001). Pathogenesis of Marek's disease virus infection. Curr. Top. Microbiol. Immunol. 255, 25-55.

Chuang, L. S., Ian, H. I., Koh, T. W., Ng, H. H., Xu, G., and Li, B. F. (1997). Human DNA-(cytosine-5) methyltransferase-PCNA complex

\section{AUTHORS' CONTRIBUTIONS}

Juan Luo extracted DNA and RNA, performed the DNA methylation and mRNA expression experiments, analyzed the data and wrote the paper. Ying Yu extracted some of the DNA and performed some of the DNA methylation analysis. Fei Tian extracted DNA and RNA. Shuang Chang conducted the challenge trials and collected samples. Huanmin Zhang revised the paper. Jiuzhou Song designed the experiments and revised the paper.

\section{ACKNOWLEDGMENTS}

The work was supported by USDA-NRI/NIFA 2008-35204-04660 and USDA-NRI/NIFA 2010-65205-20588.

Zhou, H. (2010). Marek's disease virus-induced immunosuppression: array analysis of chicken immune response gene expression profiling. Viral Immunol. 23, 309-319.

Jelinek, J., Gharibyan, V., Estecio, M. R., Kondo, K., He, R., Chung, W., Lu, Y., Zhang, N., Liang, S., and Kantarjian, H. M., Cortes, J. E., and Issa, J. P. (2011). Aberrant DNA methylation is associated with disease progression, resistance to imatinib and shortened survival in chronic myelogenous leukemia. PLoS ONE 6, e22110. doi:10.1371/journal.pone.0022110

Kaiser, P., Underwood, G., and Davison, F. (2003). Differential cytokine responses following Marek's disease virus infection of chickens differing in resistance to Marek's disease. J. Virol. 77, 762-768.

Katto, J., and Mahlknecht, U. (2011). Epigenetic regulation of cellular adhesion in cancer. Carcinogenesis 32, 1414-1418.

Liu, H. C., Cheng, H. H., Tirunagaru, V., Sofer, L., and Burnside, J. (2001). A strategy to identify positional candidate genes conferring Marek's disease resistance by integrating DNA microarrays and genetic mapping. Anim. Genet. 32, 351-359.

Luo, J., Yu, Y., and Song, J. (2012). "Epigenetics and animal health," in Livestock Epigenetics, ed. H. Khatib (Oxford: Wiley-Blackwell), doi: 10.1002/9781119949930.ch8

Luo, J., Yu, Y., Zhang, H., Tian, F., Chang, S., Cheng, H. H., and Song, J. (2011). Down-regulation of promoter methylation level of CD4 gene after MDV infection in MDsusceptible chicken line. BMC Proc. 5(Suppl. 4), S7.

Morimura, T., Ohashi, K., Kon, Y., Hattori, M., Sugimoto, C., and Onuma, M. (1996). Apoptosis and CD8-down-regulation in the thymus of chickens infected with Marek's disease virus. Arch. Virol. 141, 2243-2249.
Novak, P., Jensen, T. J., Garbe, J. C., Stampfer, M. R., and Futscher, B. W. (2009). Stepwise DNA methylation changes are linked to escape from defined proliferation barriers and mammary epithelial cell immortalization. Cancer Res. 69, 5251-5258.

Osterrieder, N., Kamil, J. P., Schumacher, D., Tischer, B. K., and Trapp, S. (2006). Marek's disease virus: from miasma to model. Nat. Rev. Microbiol. 4, 283-294.

Parcells, M. S., and Burgess, S. C. (2008). Immunological aspects of Marek's disease virus (MDV)-induced lymphoma progression. Cancer Growth Progression 11, 169.

Robert, M. F., Morin, S., Beaulieu, N., Gauthier, F., Chute, I. C., Barsalou, A., and MacLeod, A. R. (2003). DNMT1 is required to maintain CpG methylation and aberrant gene silencing in human cancer cells. Nat. Genet. 33, 61-65.

Sarson, A. J., Parvizi, P., Lepp, D., Quinton, M., and Sharif, S. (2008a). Transcriptional analysis of host responses to Marek's disease virus infection in genetically resistant and susceptible chickens. Anim. Genet. 39, 232-240.

Sarson, A. J., Abdul-Careem, M. F., Read, L. R., Brisbin, J. T., and Sharif, S. (2008b). Expression of cytotoxicityassociated genes in Marek's disease virus-infected chickens. Viral Immunol. 21, 267-272.

Soejima, K., Fang, W., and Rollins, B. J. (2003). DNA methyltransferase $3 \mathrm{~b}$ contributes to oncogenic transformation induced by SV40T antigen and activated Ras. Oncogene 22, 4723-4733.

Thanthrige-Don, N., Read, L. R., AbdulCareem, M. F., Mohammadi, H., Mallick, A. I., and Sharif, S. (2010). Marek's disease virus influences the expression of genes associated with IFN-gamma-inducible MHC class II expression. Viral Immunol. 23, 227-232.

Tsai, C. N., Tsai, C. L., Tse, K. P., Chang, H. Y., and Chang, 
Y. S. (2002). The Epstein-Barr virus oncogene product, latent membrane protein 1 , induces the downregulation of E-cadherin gene expression via activation of DNA methyltransferases. Proc. Natl. Acad. Sci. U.S.A. 99, 10084-10089.

Witter, R. L. (1997). Increased virulence of Marek's disease virus field isolates. Avian Dis. 41, 149-163.

Yamasaki, H., Mesnil, M., Omori, Y., Mironov, N., and Krutovskikh, V. (1995). Intercellular communication and carcinogenesis. Mutat. Res. 333, 181-188.

Young, W. B., Lindberg, G. L., Link, C. J. Jr. (2000). DNA methylation of helper virus increases genetic instability of retroviral vector producer cells. J. Virol. 74, 3177-3187.
Yu, Y., Luo, J., Mitra, A., Chang, S., Tian, F., Zhang, H., Yuan, P., Zhou, H., and Song, J. (2011). Temporal transcriptome changes induced by MDV in marek's disease-resistant and -susceptible inbred chickens. BMC Genomics 12:501.

Yu, Y., Zhang, H., Tian, F., Zhang, W., Fang, H., and Song, J. (2008a). An integrated epigenetic and genetic analysis of DNA methyltransferase genes (DNMTs) in tumor resistant and susceptible chicken lines. PLoS ONE 3, e2672. doi:10.1371/journal.pone.0002672

Yu, Y., Zhang, H., Tian, F., Bacon, L., Zhang, Y., Zhang, W., and Song, J. (2008b). Quantitative evaluation of DNA methylation patterns for $A L V E$ and $T V B$ genes in a neoplastic disease susceptible and resistant chicken model. PLoS ONE 3, e1731. doi: 10.1371/journal.pone. 0001731

Zheng, D. L., Zhang, L., Cheng, N., Xu, X., Deng, Q., Teng, X. M., Wang, K. S., Zhang, X., Huang, J., and Han, Z. G. (2008). Epigenetic modification induced by hepatitis $\mathrm{B}$ virus $\mathrm{X}$ protein via interaction with de novo DNA methyltransferase DNMT3A. J. Hepatol. 50, 377-387.

Conflict of Interest Statement: The authors declare that the research was conducted in the absence of any commercial or financial relationships that could be construed as a potential conflict of interest.
Received: 08 November 2011; accepted: 30 January 2012; published online: 17 February 2012

Citation: Luo J, Yu Y, Chang S, Tian F, Zhang H and Song J (2012) DNA methylation fluctuation induced by virus infection differs between MD-resistant and -susceptible chickens. Front. Gene. 3:20. doi: 10.3389/fgene.2012.00020

This article was submitted to Frontiers in Epigenomics, a specialty of Frontiers in Genetics.

Copyright (C) 2012 Luo, Yu, Chang, Tian, Zhang and Song. This is an open-access article distributed under the terms of the Creative Commons Attribution Non Commercial License, which permits noncommercial use, distribution, and reproduction in other forums, provided the original authors and source are credited. 


\section{APPENDIX}

Table A1 | Primers for pyrosequencing analysis of promoter methylation.

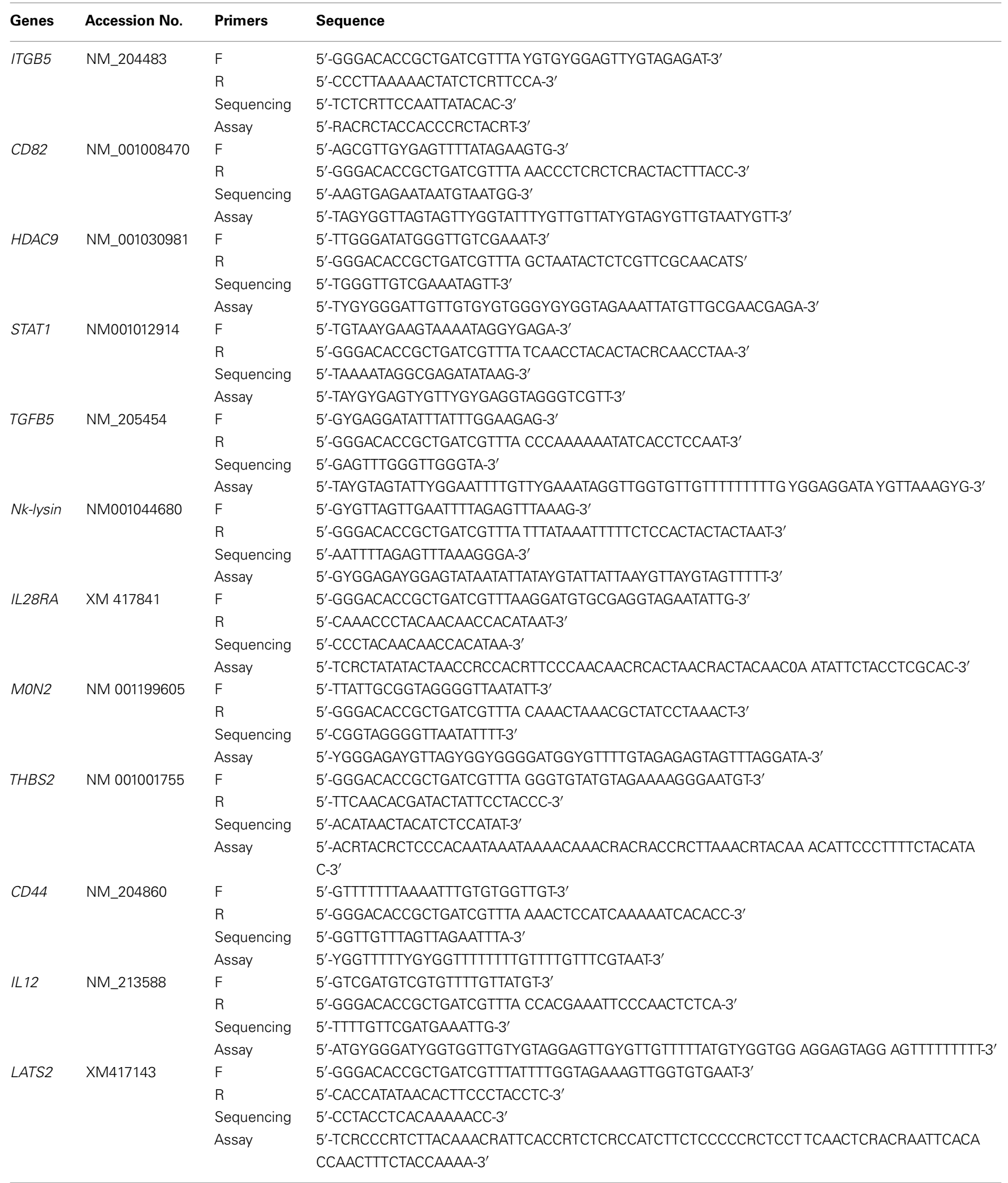


Table A1 | Continued

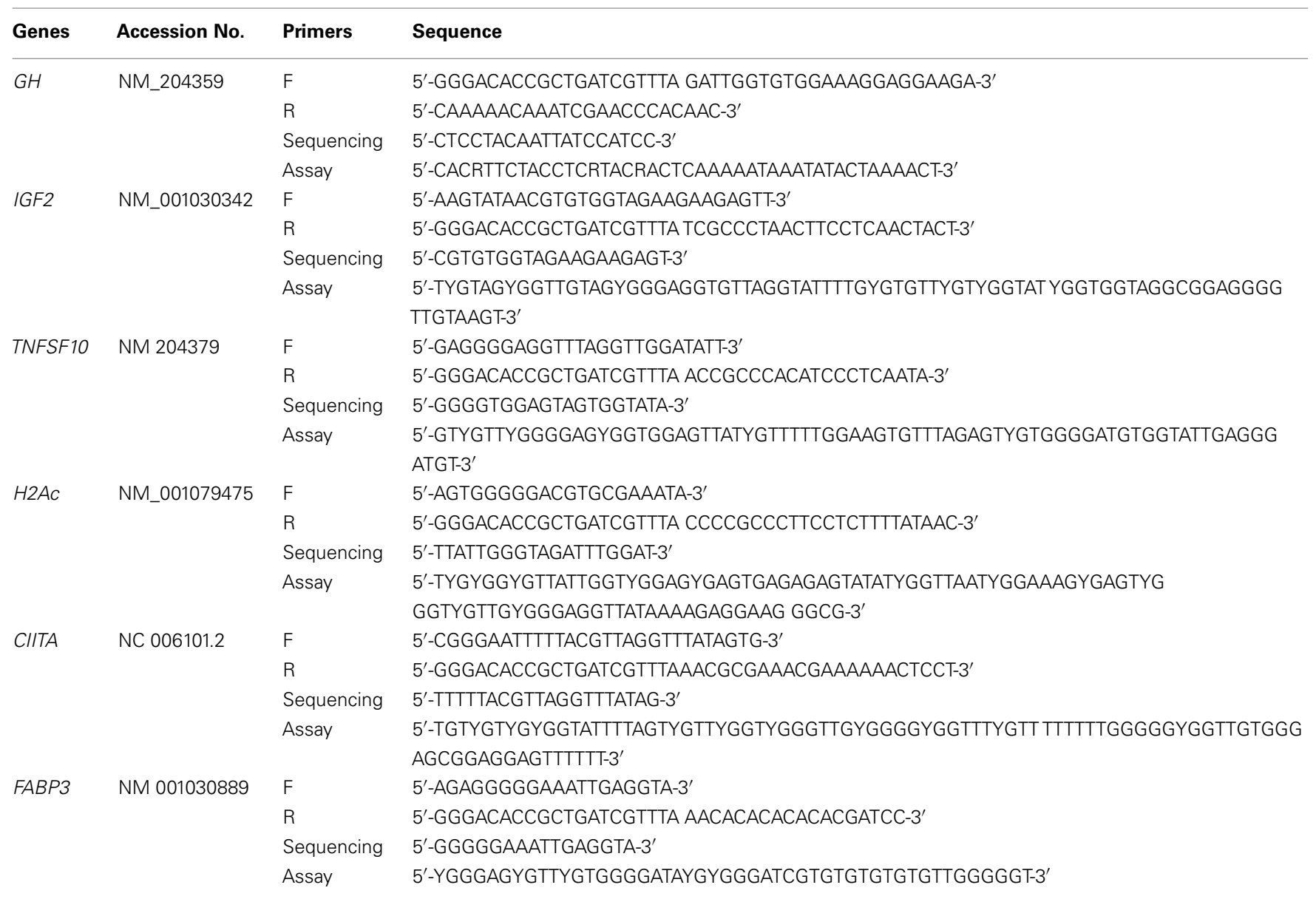

Y stands for $C / T$, and $R$ stands for G/A. Bold Y or $R$ in the assay sequence is the CpG sites analyzed in each region.

Table A2 | Primers for quantitative real-time RT-PCR.

\begin{tabular}{|c|c|c|}
\hline Genes & Primers & Sequence \\
\hline & $\mathrm{R}$ & 5'-TCATCCTTGCAGTGCTTTTG-3' \\
\hline & $\mathrm{R}$ & 5'-GTCAGGTACTCCAGCACGG-3' \\
\hline \multirow[t]{2}{*}{ DNMT1 } & $\mathrm{F}$ & 5'-CCACCAAAAGGAAATCAGAG-3' \\
\hline & $\mathrm{R}$ & 5'-ТААТССТСТTСТСАТСТTGСТ-3' \\
\hline & $\mathrm{R}$ & 5'-GCAAAGAGGTGGCGGATCAC-3' \\
\hline \multirow[t]{2}{*}{ DNMT3b } & $\mathrm{F}$ & 5'-CGTTACTTCTGGGGCAACCTC-3' \\
\hline & $\mathrm{R}$ & 5'-ATGACAGGGATGCTCCAGGAC-3' \\
\hline \multirow[t]{2}{*}{ GAPDH } & $\mathrm{F}$ & 5'-GAGGGTAGTGAAGGCTGCTG-3' \\
\hline & $\mathrm{R}$ & 5'-ACCAGGAAACAAGCTTGACG-3' \\
\hline
\end{tabular}


Table A3 | Promoter Methylation levels of $\mathrm{LG}_{3}$ and $\mathrm{LT}_{2}$ not challenged with MDV.

\begin{tabular}{|c|c|c|c|c|c|c|c|c|c|c|}
\hline \multirow[t]{2}{*}{ Genes } & \multirow[t]{2}{*}{ Lines } & \multicolumn{8}{|c|}{ CpG sites } & \multirow{2}{*}{$\begin{array}{l}\text { Note } \\
\text { Hypo. }\end{array}$} \\
\hline & & 1 & 2 & 3 & 4 & 5 & 6 & 7 & 8 & \\
\hline & $\mathrm{L}_{2}$ & $0.78 \pm 0.97$ & $0.67 \pm 0.88$ & $3.20 \pm 1.32$ & $0.78 \pm 0.89$ & $1.30 \pm 1.22$ & $0.81 \pm 1.27$ & $2.09 \pm 2.80$ & $0.56 \pm 0.70$ & \\
\hline \multirow[t]{2}{*}{ MON2 } & $\mathrm{L}_{3}$ & $1.04 \pm 1.37$ & $1.50 \pm 1.48$ & $1.59 \pm 1.80$ & $0.99 \pm 1.80$ & $0.57 \pm 1010$ & N/A/A & N/A/A & N/A/A & \\
\hline & $\mathrm{L}_{2}$ & $1.94 \pm 1.11$ & $1.34 \pm 1.50$ & $2.47 \pm 3.25$ & $1.53 \pm 2.09$ & $1.01 \pm 1.30$ & N/A/A & N/A/A & N/A/A & \\
\hline & $\mathrm{L} 7_{2}$ & $3.90 \pm 1.08$ & $7.95 \pm 1.34$ & $2.49 \pm 0.56$ & $5.10 \pm 1.75$ & $3.90 \pm 1.38$ & N/A/A & N/A/A & N/A/A & \\
\hline \multirow[t]{2}{*}{ STAT1 } & $\mathrm{L}_{3}$ & $1.41 \pm 1.31$ & $2.22 \pm 1.22$ & $2.97 \pm 1.48$ & $2.59 \pm 1.76$ & $1.26 \pm 1.17$ & $1.98 \pm 1.27$ & N/A/A & N/A/A & \\
\hline & $\mathrm{L} 7_{2}$ & $1.06 \pm 1.28$ & $3.26 \pm 1.93$ & $2.91 \pm 1.65$ & $3.10 \pm 0.70$ & $0.71 \pm 1.07$ & $1.50 \pm 1.47$ & N/A/A & N/A/A & \\
\hline \multirow[t]{2}{*}{ CD44 } & $\mathrm{L}_{3}$ & $1.53 \pm 0.60$ & $20.72 \pm 7.08$ & $0.58 \pm 0.16$ & $15.10 \pm 3.39$ & N/A/A & N/A/A & N/A/A & N/A/A & \\
\hline & $\mathrm{L} 7_{2}$ & $1.94 \pm 1.02$ & $6.73 \pm 1.43$ & $3.04 \pm 0.91$ & $6.76 \pm 0.93$ & N/A/A & N/A/A & N/A/A & N/A/A & \\
\hline $\mathrm{H} 2 \mathrm{Ac}$ & $\mathrm{L}_{3}$ & $4.33 \pm 0.57$ & $3.55 \pm 0.59$ & $21.51 \pm 1.32$ & $29.03 \pm 1.76$ & $14.83 \pm 0.81$ & $10.09 \pm 0.74$ & N/A/A & N/A/A & \\
\hline \multirow[t]{2}{*}{ IL12 } & $\mathrm{L}_{3}$ & $19.38 \pm 6.42$ & $12.38 \pm 4.22$ & $15.60 \pm 3.94$ & $17.02 \pm 4.29$ & $7.43 \pm 1.76$ & N/A/A & N/A/A & N/A/A & \\
\hline & $\mathrm{L} 7_{2}$ & $24.25 \pm 4.29$ & $14.57 \pm 3.30$ & $18.30 \pm 2.01$ & $21.22 \pm 4.25$ & $8.78 \pm 2.16$ & N/A/A & N/A/A & N/A/A & \\
\hline \multirow[t]{2}{*}{$F A B P 3$} & $\mathrm{~L}_{3}$ & $35.99 \pm 7.36$ & $35.24 \pm 4.20$ & $48.05 \pm 7.12$ & $32.69 \pm 4.39$ & $4.16 \pm 1.81$ & $20.43 \pm 8.12$ & N/A/A & N/A/A & \\
\hline & $\mathrm{L}_{2}$ & $28.22 \pm 6.60$ & $30.27 \pm 8.05$ & $39.98 \pm 12.15$ & $28.38 \pm 7.52$ & $4.85 \pm 1.46$ & $17.03 \pm 5.14$ & N/A/A & N/A/A & \\
\hline \multirow[t]{2}{*}{ CIITA } & $\mathrm{L}_{3}$ & $25.57 \pm 4.55$ & $29.20 \pm 6.72$ & $4.26 \pm 3.64$ & $3.22 \pm 2.96$ & N/A/A & N/A/A & N/A/A & N/A/A & \\
\hline & $\mathrm{L}_{2}$ & $19.76 \pm 7.59$ & $24.70 \pm 8.94$ & $4.56 \pm 4.72$ & $4.30 \pm 5.96$ & N/A/A & N/A/A & N/A/A & N/A/A & \\
\hline \multirow[t]{2}{*}{ ITGB5 } & $\mathrm{L}_{3}$ & $38.62 \pm 4.45$ & $46.81 \pm 4.08$ & $61.94 \pm 4.47$ & $44.06 \pm 4.88$ & $37.74 \pm 1.32$ & $39.63 \pm 1.57$ & N/A/A & N/A/A & Inter. \\
\hline & $\mathrm{L}_{2}$ & $52.04 \pm 4.62$ & $61.32 \pm 4.76$ & $71.83 \pm 3.54$ & $56.37 \pm 4.09$ & $40.05 \pm 1.86$ & $41.53 \pm 5.97$ & N/A/A & N/A/A & \\
\hline \multirow[t]{2}{*}{ THBS2 } & $\mathrm{L}_{3}$ & $34.31 \pm 5.01$ & $54.07 \pm 6.46$ & $32.32 \pm 4.90$ & $22.03 \pm 3.13$ & $11.37 \pm 1.85$ & N/A/A & N/A/A & N/A/A & \\
\hline & $\mathrm{L} 7_{2}$ & $49.45 \pm 5.16$ & $70.68 \pm 5.04$ & $41.68 \pm 4.63$ & $30.91 \pm 3.82$ & $14.08 \pm 1.45$ & N/A/A & N/A/A & N/A/A & \\
\hline HDAC9 & $\mathrm{L}_{3}$ & $24.83 \pm 6.00$ & $31.65 \pm 6.03$ & $51.50 \pm 5.82$ & $55.74 \pm 4.78$ & $40.77 \pm 6.22$ & N/A/A & N/A/A & N/A/A & \\
\hline \multirow[t]{2}{*}{ TGFB3 } & $\mathrm{L}_{3}$ & $88.04 \pm 1.60$ & $90.98 \pm 2.19$ & $90.39 \pm 2.28$ & $80.86 \pm 1.60$ & $68.43 \pm 2.13$ & $74.39 \pm 3.46$ & N/A/A & N/A/A & \\
\hline & $\mathrm{L} 7_{2}$ & $89.88 \pm 2.59$ & $92.91 \pm 2.58$ & $93.51 \pm 2.66$ & $82.90 \pm 2.09$ & $72.94 \pm 3.09$ & $77.00 \pm 2.68$ & N/A/A & N/A/A & \\
\hline \multirow[t]{2}{*}{ CD82 } & $\mathrm{L}_{3}$ & $3.86 \pm 1.56$ & $5.24 \pm 1.86$ & $3.97 \pm 1.61$ & $3.98 \pm 0.98$ & $3.65 \pm 2.02$ & $1.88 \pm 1.36$ & $40.48 \pm 5.54$ & $52.78 \pm 3.63$ & Hypo + \\
\hline & $\mathrm{L} 7_{2}$ & $3.16 \pm 0.99$ & $4.41 \pm 1.31$ & $3.59 \pm 1.12$ & $4.41 \pm 1.40$ & $2.69 \pm 1.23$ & $1.85 \pm 1.27$ & $41.22 \pm 5.29$ & $51.61 \pm 2.67$ & Inter. \\
\hline
\end{tabular}

Methylation level shown in each cell = mean \pm STD.

Hypo., hypomethylation; Hyper., hypermethylation; Inter., intermediate methylation.

$N / A$, data not available.

$N=12$ for each group. 
Table A4 | Promoter methylation level change at different CpG sites of genes after MDV challenge.

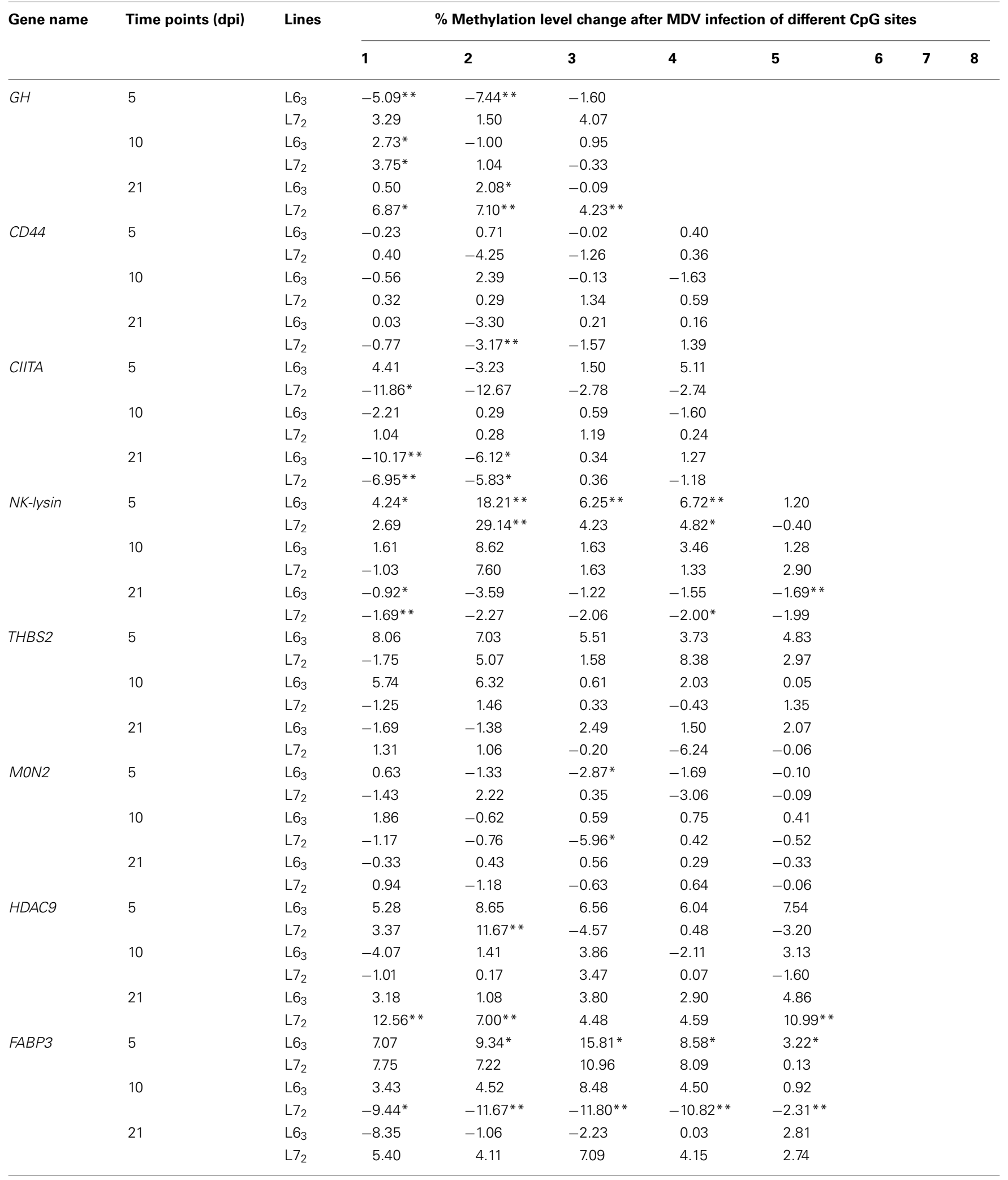


Table A4 | Continued

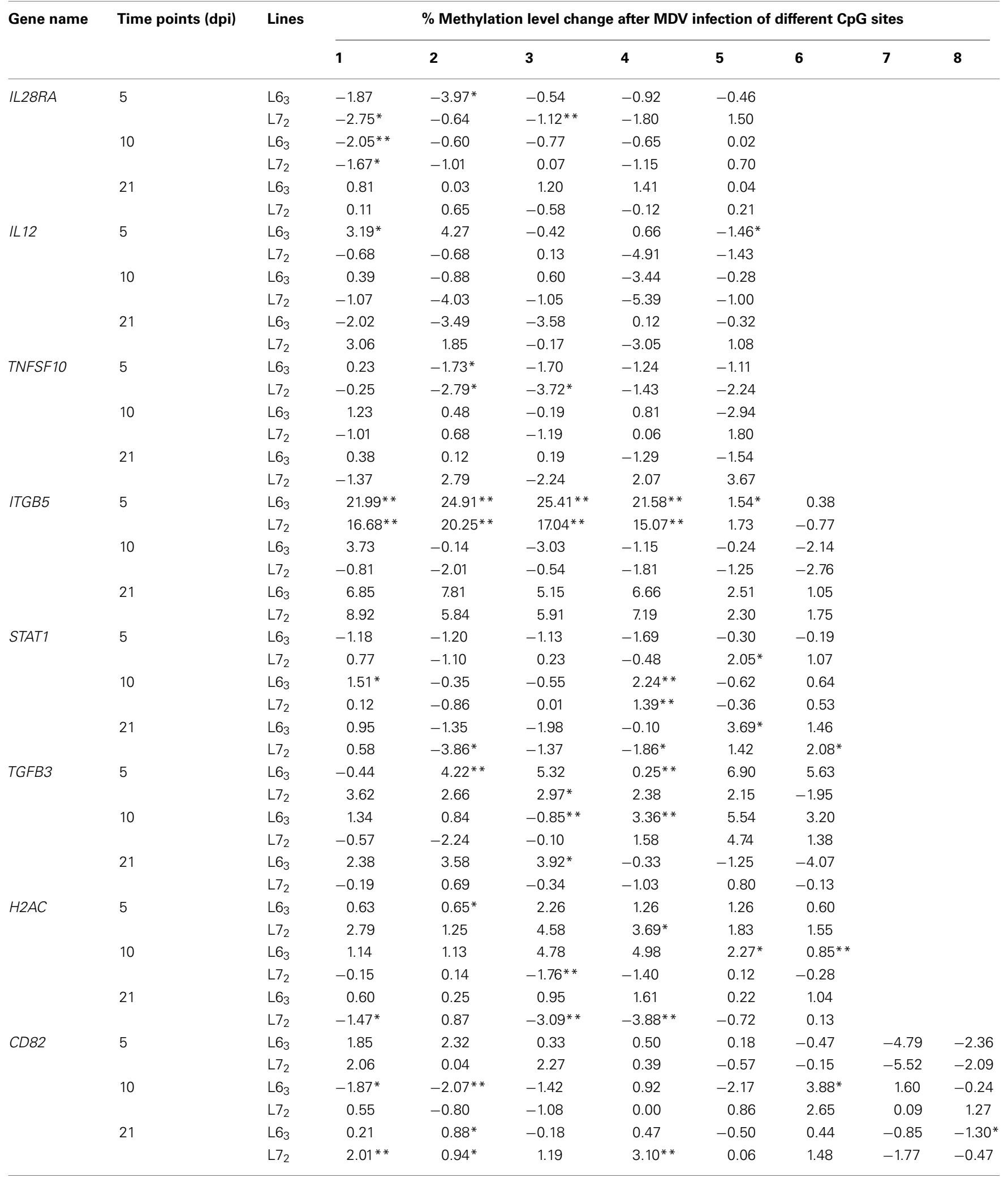


Table A4 | Continued

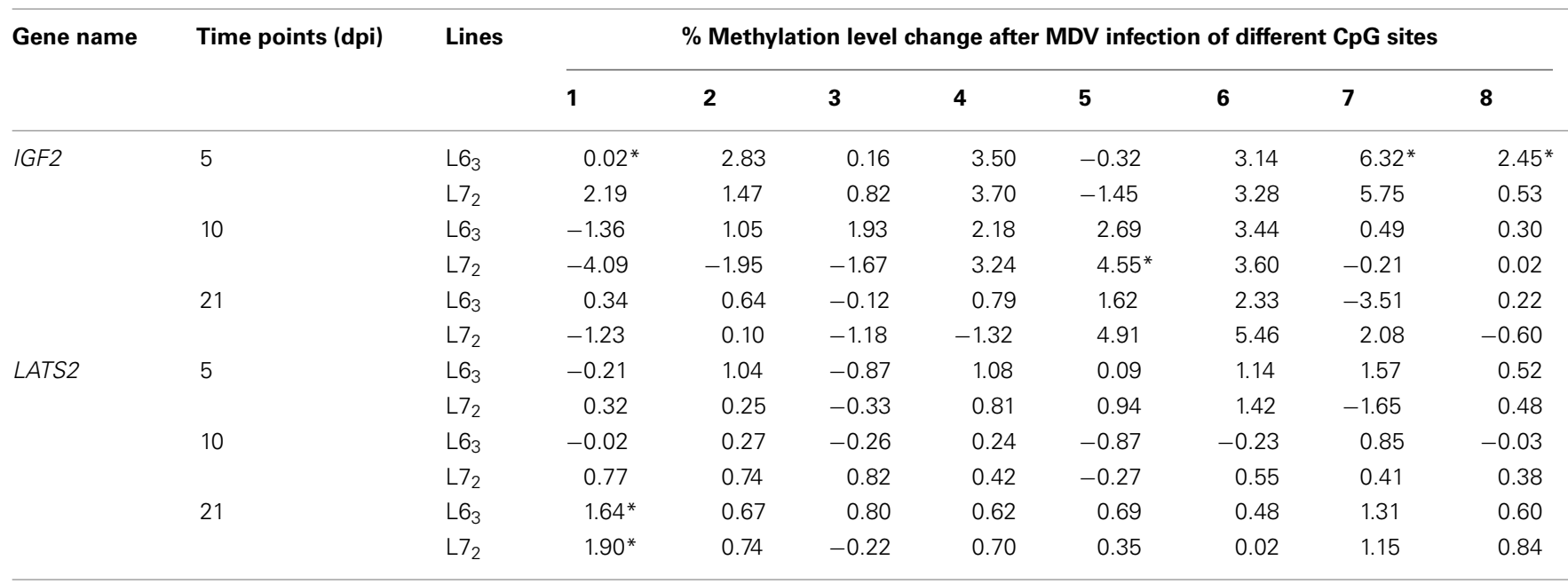

${ }^{*} P<0.05,{ }^{*} P<0.01$. 


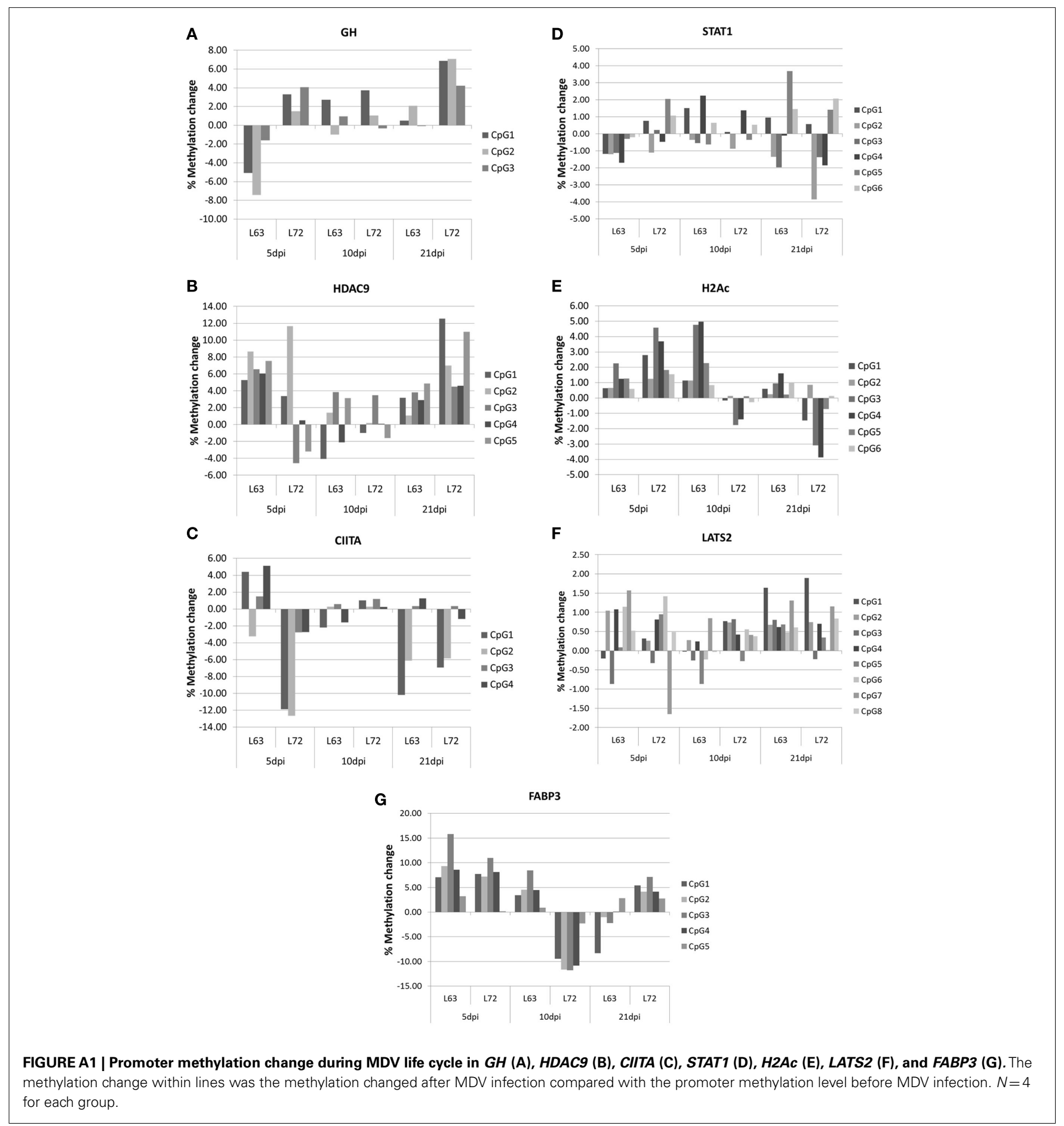

